\title{
Farklı Anız Yükseklikleri Kalacak Şekilde Yapılan Biçimlerin Arpanın Ot Verimi ve Kalitesine Etkileri
}

\author{
Ahmet GÖKKUŞ ${ }^{1} \quad$ Selçuk BİRER ${ }^{2} \quad$ Firat ALATÜRK ${ }^{1}$ \\ ${ }^{1}$ ÇOMÜ Ziraat Fakültesi Tarla Bitkileri Bölümü, ÇANAKKALE \\ ${ }^{2}$ ÇOMÜ Bayramiç MYO, ÇANAKKALE \\ $\triangle$ : alaturkf@comu.edu.tr
}

Geliş (Received): 03.11.2017

Kabul (Accepted): 15.12.2017

\begin{abstract}
ÖZET: $\mathrm{Bu}$ araștırma, meralar üzerinde otlatma baskısını azaltmak ve kaliteli kaba yem açığını kapatmak için arpadan oluşan hasıl meralarda otlatmayı taklit etmek üzere yapılan farklı anız yüksekliklerinden $(5,7.5,10,12.5$ ve $15 \mathrm{~cm}$ ) biçimin ot verimi ve kalitesi üzerine etkilerini belirlemek amaciyla yürütülmüştür. Bu amaçla deneme 201415 ve 2015-16 yetiștirme dönemlerinde ÇOMÜ Dardanos Yerleşkesindeki Ziraat Fakültesi uygulama alanında tesadüf blokları deneme desenine göre 3 tekerrürlü olarak yürütülmüştür. Biçimde $5,7.5$ ve $12.5 \mathrm{~cm}$ anız bırakılan parsellerde toplam 3 biçim, 10 ve $15 \mathrm{~cm}$ anız kalacak şekilde biçilenlerde ise 4 biçim yapılmıştır. Araştırma sonuçlarına göre, en yüksek toplam ot verimi (yeşil ot $1206.4 \mathrm{~kg} \mathrm{da}^{-1}$ ve kuru ot $494.1 \mathrm{~kg} \mathrm{da}^{-1}$ ) $10 \mathrm{~cm}$ anız kalacak şekilde yapılan biçimden elde edilmiştir. Otun besin maddesi üzerinde anız yüksekliklerinin önemli etkisi olmamıştır. Biçim sayısının artışına bağlı olarak ot verimi ile otun ham protein, sindirilebilir organik ve kuru madde oranları azalmış; ham kül, NDF ve ADF oranları artmıştır. Genel olarak arpa meraları ekimden itibaren 150-160 günde otlatma olgunluğuna ulaşabilmekte ve biçim (otlatma) yüksekliği ve iklime bağlı olarak iki otlatma arasında 11-42 gün geçmektedir. Çalışmada arpa ile oluşturulacak hasıl meraların 20-25 cm boylanınca otlatmaya başlanıp, $10 \mathrm{~cm}$ anız kalınca son verilmesi gerektiği sonucuna varılmıștır.
\end{abstract}

Anahtar Kelimeler: Arpa merası, biçim yüksekliği, ot verimi, ham protein, sindirilebilirlik.

\section{Effects of Harvesting on Yield and Quality of Barley Hay Leaving Different Formations of Stalk Heights}

ABSTRACT: This research was conducted to determine the effects of different stalk heights $(5,7.5,10,12.5$ and $15 \mathrm{~cm}$ ) on hay yield and quality to simulate grazing in barley produced pastures to reduce grazing pressure onto pastures for covering the gap of quality roughage. For this purpose, the experiment was carried out in the Application and Research Area of the Faculty of Agriculture situated in Dardanelles Campus of Çanakkale Onsekiz Mart University during 2014-15 and 2015-16 growing seasons according to the randomized complete block design using 3 replications. A total of 3 harvesting have been done in the plots where $5,7.5$ and $12.5 \mathrm{~cm}$ stalks were left, while 4 harvesting were done in those plots containing 10 and $15 \mathrm{~cm}$ stalk in harvesting. According to the results of research, the highest total hay yield (fresh hay $1206.4 \mathrm{~kg} \mathrm{da}^{-1}$ and dry hay $494.1 \mathrm{~kg} \mathrm{da}^{-1}$ ) was obtained from the harvest that has been done by leaving $10 \mathrm{~cm}$ stalk height. There was no significant effect of stalk heights on nutrient contents of hay. The ratios of SOM and SKM, hay yield and pure protein of hay decreased, while the ratios of pure ash, NDF and ADF increased depending on increase in number of harvesting. Generally, the barley pastures can reach to its grazing level within 150-160 days after sowing and takes 11-42 days between two harvesting (grazing) depending on harvesting height. It has been concluded that the grazing, in pastures produced with barley, should be started at a height of $22.5 \mathrm{~cm}$ and given an end to grazing when stalks reach at $10 \mathrm{~cm}$ of height.

Keywords: Barley pasture, harvesting height, hay yield, crude protein, digestibility

\section{GİRiș}

Türkiye'de hayvancıllğın temel sorunu yeterli ve nitelikli kaba yem üretiminin az olmasıdır. Tarla alanlarında üretilen yem bitkilerinin yeterli olmaması hem hayvanların verim güçlerinin azalmasına hem de meraların yükünün artmasına sebep olmaktadır. $\mathrm{Bu}$ duruma çözüm üretmek için son yillarda baklagil ve buğdaygil yem bitkilerinin saf ve karışık ekimlerinden oluşan yapay mera tesislerinin kurulması hız kazanmıştır (Genç, 2011). Bu nedenle biçim/otlatmadan sonra yeniden büyüme özelliğine sahip tahıl meraları gibi kısa süreli yapay meralar oluşturularak kaba yem açı̆̆ını kapatmak ve diğer yem kaynakları üzerindeki otlatma baskısını azaltmak birçok araştırmacı tarafindan önerilmektedir (Gökkuş ve ark., 2005; Ouédraogo-Koné ve ark., 2006). Tahıllar, dünyada olduğu gibi ülkemizde de en çok yetiştirilen bitki grubudur. Son yıllarda kaba yem üretmek amacıyla özellikle fiğ türleriyle karışık ekimler yaygınlaşmıştır. Tahıllar hem biçilerek hem de hasıl olarak otlatılmak suretiyle kaba yem ihtiyacinı karşılamaktadır. Özellikle başaklanmadan önceki dönemlerinde karbonhidrat ve sindirilebilme oranları oldukça yüksek seviyededir (Baytekin ve ark., 2005). Çevreye uyum yeteneklerinin oldukça iyi olması yanında besleme değerlerinin de yüksek olması, kaba yem olarak kullanımlarını yaygınlaştıran en önemli özelliklerindendir. Bunun yanında çimlenmeden sonra hızlı gelişme göstererek kısa zamanda otlatma 
olgunluğuna gelmektedirler. Kışlık ekilen buğday merasının hızlı büyüme ve soğuklara karşı dayanımı nedeniyle ilkbaharda doğal meradan yaklaşık 1 ay önce otlatma olgunluğuna ulaşmaktadır (Krenzer, 1994; Gökkuş ve Hakyemez, 2001). Ayrıca süt keçiciliğinde önemli bir yer teşkil etmektedir (Gökkuş ve ark., 2005). Böyle meralar ilkbahar ve kış soğuklarına karşı dayanıklı olup, tane ve yeşil ot üretmek amacıyla yetiştirilebilmektedir (Pinchak ve ark., 1989). Çanakkale'de 2003 ve 2004 yıllarında doğal ve buğday merasında farklı yoğunluklarda otlatmanın ot verimi ve keçilerin süt verimleri üzerine etkileri incelendiği araştırmada, buğday merasının ot verimi, yenen ot miktarı ve keçilerin süt verimi doğal meradan daha yüksek çıkmış, otlatma yoğunluğu arttıkça süt veriminde önemli bir değişim olmazken, meraların kuru ot verimi azalmış, yenen ot verimi ve oranlarında artış görülmüştür (Gökkuş ve ark., 2005). Dolayısıyla serin iklim tahılları otlayan hayvanlara yeterli ve nitelikli yem sunmaktadır. Bu amaçla kullanılan tahıllardan biri de arpadır. Bu bitki daha çok yarı-kurak bölgelerde kullanılmakta olup, tuzlu topraklara da dayanıklıdır. Otunun sindirilebilir kuru maddesi ve sindirilebilir enerji değeri yüksektir (Joyce ve ark., 1971).

$\mathrm{Bu}$ nedenle bu çalışmada, Çanakkale meralarındaki otlatma baskısını azaltmak ve alternatif kaba yem kaynağı oluşturmak için arpanın yalın ekimleri ile oluşturulan hasıl alanlarında otlatmayı taklit etmek amacıyla farklı anız yükseklikleri kalacak şekilde yapılan biçimlerde otun verim ve kalite özelliklerindeki değişim incelenmiştir.

\section{MATERYAL ve YÖNTEM}

Deneme 2014-15 ve 2015-16 yillarında ÇOMÜ Dardanos yerleşkesindeki deneme alanında yürütülmüștür. Denemenin yürütüldüğü dönemde aylık ortalama sıcaklık ilk y1l $16.4^{\circ} \mathrm{C}$, ikinci yıl ise $17.8^{\circ} \mathrm{C}$ olup, uzun yillara göre $\left(15.4^{\circ} \mathrm{C}\right)$ göre daha yüksek değerlere sahip olmuştur. Yıllık toplam yağış miktarı ilk yil $(726.6 \mathrm{~mm})$ uzun yillar ortalamasinın $(670.2 \mathrm{~mm})$ üzerinde, ikinci yıl $(650.1 \mathrm{~mm})$ ise altında kalmıştır Deneme alanı toprakları killi-tınlı bünyeye sahip olup, orta kireçli, azot ve fosfor bakımından yetersiz, potasyum bakımından yeterli ve organik maddece fakirdir.

Bitki materyali olarak arpanın Manava çeşidi kullanılmıştır. Araştırma tesadüf blokları deneme desenine göre 3 tekerrürlü olarak kurulmuştur. Denemede parsel genişliği $1.5 \mathrm{~m}$, parsel uzunluğu $5 \mathrm{~m}$, toplam parsel alanı $7.5 \mathrm{~m}^{2}$, parseller aras $0.5 \mathrm{~m}$ ve bloklar arası ise $1 \mathrm{~m}$ olacak şekilde tanzim edilmiştir. Araştırmada bırakılan anız yüksekliği faktör olarak ele alınmış ve bitkiler 5, 7.5, 10, 12.5 ve $15 \mathrm{~cm}$ anız kalacak şekilde biçilmiştir. Tüm parsellerde bitkilerin boyu yaklaşık 20-25 cm'ye geldiğinde (otlatma olgunluğuna eriştiğinde) hasat edilmiştir (Hennessy ve Clements, 2009). Biçimde $5 \mathrm{~cm}$ anız ile ağır, $10 \mathrm{~cm}$ anız ile orta ve $15 \mathrm{~cm}$ anız ile hafif otlatma taklit edilmiştir. Denemede gübreleme ve sulama yapılmamış, yabancı otlar elle yok edilmiştir. Araştırmada ot verimi, ham protein (HP), ham kül (HK), NDF, ADF, sindirilebilir organik madde (SOM) ve sindirilebilir kuru madde (SKM) incelenmiştir. HP ve HK analizleri AOAC (1990)'a göre, NDF ve ADF analizleri ise Van Soest ve ark. (1991)'na göre yapılmıştır. SOM ve SKM değerleri NIR cihazı ile tespit edilmiştir. Araştırma iki yıl yürütülmüş, fakat varyans analizinde iki yıllık ortalama veriler kullanılmıştır. Varyans analizi SAS istatistik paket programı yardımıyla yapılmıştır (SAS, 1999).

\section{BULGULAR ve TARTIŞMA}

Ot verimi: Arpanın yeşil ot verimi üzerine biçim sayısı ile anız yüksekliği*biçim sayısı etkileşimi önemli, anız yüksekliğinin etkisi ise önemsiz olmuştur. Bütün biçimlerin toplamı olarak en yüksek yeşil (1206.4 kg da$\left.{ }^{1}\right)$ ve kuru ot üretimi (494.1 $\left.\mathrm{kg} \mathrm{da}^{-1}\right) 10 \mathrm{~cm}$ anız kalacak şekilde yapılan biçimlerden elde edilmiştir.

Çizelge 1. Farklı anız yükseklikleri kalacak şekilde biçilen arpanın yeşil ve kuru ot verimleri $\left(\mathrm{kg} \mathrm{da}^{-1}\right)$

\begin{tabular}{|c|c|c|c|c|c|c|}
\hline \multirow{2}{*}{$\begin{array}{c}\text { Anız yükssekliği } \\
(\mathbf{c m})\end{array}$} & \multicolumn{5}{|c|}{ Biçim sayısı } & \multirow{2}{*}{ Toplan } \\
\hline & 1 & 2 & 3 & 4 & Ortalama & \\
\hline \multicolumn{7}{|c|}{ Yeşil ot verimi } \\
\hline 5 & $614.1 \mathrm{a}$ & $262.1 \mathrm{cde}$ & $100.0 \mathrm{fg}$ & - & 412.1 & 976.3 \\
\hline 7,5 & $492.2 \mathrm{~b}$ & 257.9 cde & $198.4 \mathrm{def}$ & - & 339.7 & 948.5 \\
\hline 10 & $523.8 \mathrm{~b}$ & $356.0 \mathrm{c}$ & 218.9 def & $107.7 \mathrm{fg}$ & 353.9 & 1206.4 \\
\hline 12,5 & $278.5 \mathrm{~cd}$ & $263.6 \mathrm{cde}$ & $184.7 \mathrm{def}$ & - & 249.5 & 726.8 \\
\hline 15 & $213.8 \mathrm{def}$ & $311.7 \mathrm{~cd}$ & $196.6 \mathrm{def}$ & 163.0 ef & 233.3 & 886.4 \\
\hline Ortalama & $424.8 \mathrm{~A}$ & $290.3 \mathrm{~B}$ & $193.8 \mathrm{BC}$ & $135.3 \mathrm{C}$ & - & 1044,2 \\
\hline Önemlilik & \multicolumn{6}{|c|}{$\mathrm{P}_{\mathrm{AY}}: 0.0530, \mathrm{P}_{\mathrm{BS}}: 0.0001, \mathrm{P}_{\mathrm{AY} * \mathrm{BS}}: 0.0001$} \\
\hline \multicolumn{7}{|c|}{ Kuru ot verimi } \\
\hline 5 & $173,4 \mathrm{~b}$ & 57,2 cde & $22,0 \mathrm{de}$ & - & 108,1 & 252,6 \\
\hline 7,5 & $127,3 \mathrm{bc}$ & 74,4 cde & 43,0 cde & - & 89,3 & 244,7 \\
\hline 10 & $315,6 \mathrm{a}$ & $105,7 \mathrm{bcd}$ & 55,3 cde & $17,5 \mathrm{e}$ & 154,7 & 494,1 \\
\hline 12,5 & 86,4 cde & 74,8 cde & 43,1 cde & - & 71,2 & 204,3 \\
\hline 15 & 64,5 cde & 85,9 cde & 56,3 cde & 37,7 cde & 65,7 & 244,4 \\
\hline Ortalama & $153,4 \mathrm{~A}$ & $79,6 \mathrm{~B}$ & $49,1 \mathrm{C}$ & $27,5 \mathrm{C}$ & - & 309,6 \\
\hline Önemlilik & $\mathrm{P}_{\mathrm{AY}}: 0,0712$, & $0,0001, \mathrm{P}_{\mathrm{AY} * \mathrm{~B}}$ & 321 & & & \\
\hline
\end{tabular}

AY: Anız yüksekliği, BS: Biçim sayısı, AY*BS: Biçim yükssekliği*Biçim sayısı 
Çizelge 2. Farklı anız yükseklikleri kalacak şekilde biçilen arpa otunun HP, HK, NDF, ADF, SOM ve SKM oranları (\%)

\begin{tabular}{|c|c|c|c|c|c|}
\hline \multirow{2}{*}{$\begin{array}{c}\text { Anız yüksekliği } \\
(\mathrm{cm})\end{array}$} & \multicolumn{4}{|c|}{ Biçim sayısı } & \multirow{2}{*}{ Ortalama } \\
\hline & 1 & 2 & 3 & 4 & \\
\hline \multicolumn{6}{|c|}{ HP oranı } \\
\hline 5 & 12.44 & 16.08 & 14.20 & - & 14.11 \\
\hline 7,5 & 13.03 & 15.44 & 16.52 & - & 14.69 \\
\hline 10 & 15.05 & 15.39 & 16.71 & 14.67 & 15.49 \\
\hline 12,5 & 13.91 & 14.30 & 16.44 & - & 14.69 \\
\hline 15 & 15.46 & 14.17 & 16.92 & 12.15 & 15.18 \\
\hline Ortalama & $13.98 \mathrm{~B}$ & $15.04 \mathrm{AB}$ & $16.43 \mathrm{~A}$ & $13.41 \mathrm{~B}$ & - \\
\hline \multicolumn{6}{|c|}{$\mathrm{P}_{\mathrm{AY}}: 0.2996, \mathrm{P}_{\mathrm{BS}}: 0.0012, \mathrm{P}_{\mathrm{AY} * \mathrm{BS}}: 0.1314$} \\
\hline \multicolumn{6}{|c|}{$\begin{array}{ll}\text { HK oranı } \\
\end{array}$} \\
\hline 5 & 10.10 & 13.68 & 11.20 & - & 11.65 \\
\hline 7,5 & 10.58 & 10.88 & 8.42 & - & 10.29 \\
\hline 10 & 10.23 & 11.24 & 8.47 & 7.26 & 9.84 \\
\hline 12,5 & 9.24 & 8.89 & 9.49 & - & 9.17 \\
\hline 15 & 10.25 & 8.44 & 9.16 & 7.72 & 9.13 \\
\hline Ortalama & 10.08 & 10.52 & 9.18 & 7.49 & - \\
\hline \multicolumn{6}{|c|}{$\mathrm{P}_{\mathrm{AY}}: 0.2659, \mathrm{P}_{\mathrm{BS}}: 0.1222, \mathrm{P}_{\mathrm{AY} * \mathrm{BS}}: 0.4543$} \\
\hline \multicolumn{6}{|c|}{ NDF oranı } \\
\hline 5 & 54.21 & 59.92 & 60.52 & - & 56.99 \\
\hline 7,5 & 53.80 & 61.93 & 60.14 & - & 58.32 \\
\hline 10 & 52.46 & 60.89 & 61.11 & 60.10 & 58.03 \\
\hline 12,5 & 52.74 & 63.87 & 60.95 & - & 58.96 \\
\hline 15 & 51.56 & 63.10 & 62.93 & 68.03 & 60.08 \\
\hline Ortalama & $52.95 \mathrm{~B}$ & $61.84 \mathrm{~A}$ & $61.43 \mathrm{~A}$ & $64.02 \mathrm{~A}$ & - \\
\hline Önemlilik & \multicolumn{3}{|c|}{ PAY: 0.1909, PBS: 0.0001, PAY*BS: 0.3170} & & \\
\hline & & & & & \\
\hline 5 & 36.87 & 38.65 & 39.74 & - & 37.99 \\
\hline 7,5 & 36.61 & 41.01 & 39.11 & - & 38.87 \\
\hline 10 & 36.17 & 40.41 & 40.89 & 39.45 & 39.00 \\
\hline 12,5 & 35.65 & 41.41 & 40.39 & - & 38.99 \\
\hline 15 & 35.79 & 41.00 & 40.22 & 41.60 & 39.26 \\
\hline Ortalama & $36.22 \mathrm{~B}$ & $40.56 \mathrm{~A}$ & $40.17 \mathrm{~A}$ & $40.53 \mathrm{~A}$ & - \\
\hline \multicolumn{6}{|c|}{$\mathrm{P}_{\mathrm{AY}}: 0.8127, \mathrm{P}_{\mathrm{BS}}: 0.0001, \mathrm{P}_{\mathrm{AY} * \mathrm{BS}}: 0.4101$} \\
\hline \multicolumn{6}{|c|}{\begin{tabular}{|ll} 
SOM oranı & \\
\end{tabular}} \\
\hline 5 & 58.11 & 46.37 & 41.56 & - & 48.74 \\
\hline $\mathbf{7 , 5}$ & 53.42 & 43.58 & 42.40 & - & 47.28 \\
\hline 10 & 55.46 & 45.31 & 43.11 & 42.89 & 47.93 \\
\hline 12,5 & 53.95 & 41.68 & 42.04 & - & 46.37 \\
\hline 15 & 55.12 & 43.88 & 43.32 & 34.87 & 46.18 \\
\hline Ortalama & $54.21 \mathrm{~A}$ & $44.09 \mathrm{~B}$ & $42.67 \mathrm{~B}$ & $38.88 \mathrm{C}$ & - \\
\hline \multicolumn{6}{|c|}{$\mathrm{P}_{\mathrm{AY}}: 0.3581, \mathrm{P}_{\mathrm{BS}}: 0.0001, \mathrm{P}_{\mathrm{AY} * \mathrm{BS}}: 0.6923$} \\
\hline \multicolumn{6}{|c|}{\begin{tabular}{|ll} 
SKM oranı \\
\end{tabular}} \\
\hline 5 & 52.08 & 46.32 & 40.56 & - & 48.09 \\
\hline 7,5 & 53.31 & 43.47 & 42.34 & - & 47.18 \\
\hline 10 & 54.76 & 45.80 & 43.73 & 42.93 & 48.01 \\
\hline 12,5 & 53.66 & 41.68 & 42.38 & - & 46.35 \\
\hline 15 & 54.69 & 44.39 & 43.28 & 34.15 & 46.12 \\
\hline Ortalama & $53.70 \mathrm{~A}$ & $44.26 \mathrm{~B}$ & $42.75 \mathrm{~B}$ & $38.54 \mathrm{C}$ & - \\
\hline Önemlilik & $\mathrm{P}_{\mathrm{AY}}: 0.2817, \mathrm{P}$ & $\mathrm{P}_{\mathrm{AY} * \mathrm{BS}}: 0.5$ & & & \\
\hline
\end{tabular}

Önemli olmamakla birlikte bırakılan anız yüksekliği arttıkça ot verimi artmıştır. Diğer taraftan biçim sayıları dikkate alındığında ise, en yüksek yeşil $\left(424.8 \mathrm{~kg} \mathrm{da}^{-1}\right)$ ve kuru ot verimi $\left(153.4 \mathrm{~kg} \mathrm{da}^{-1}\right)$ ilk, en düşük verimler (135.3 ve $27.5 \mathrm{~kg} \mathrm{da}^{-1}$ ) ise son biçimden elde edilmiştir (Çizelge 1).

Farklı anız yüksekliklerine göre ot verimlerinde önemli değişim olmamış, ancak dipten biçilen parsellerin verimi daha fazla olmuştur. Dipten biçimde her seferinde daha fazla ot kaldırıldığından, verim de yükselmiştir. Biçim sayısı ilerledikçe ot verimleri düşmüştür. Genel itibariyle ilk biçimlerde en yüksek verimlere ulaşıllırken, son biçimlerde en az verim alınmıştır. Bitkiler ilk biçimde en uzun büyüme süresine sahip olmaktadır. Sonraki biçimlerde ise hem bitkilerin üretim güçleri zayıflamakta hem de yağışın azalıp hava sıcaklığının artması (kuraklığın artması) ile büyüme için gerekli uygun şartlar azalmaktadır. Bu durum üretimin de giderek azalmasına sebep olmaktadır.

Ham protein (HP) orant: Arpa otunun HP içerikleri arasındaki farklılık biçim sayısına göre istatistiki olarak önemli olurken, anız yükseklikleri ve AY*BS 
etkileşiminde önemli olmamıştır. Bırakılan anız yüksekliklerine göre HP oranları \%14.11-15.49 arasında değişmiştir. Biçim sırasında ise en yüksek HP oranı (\%16.43) üçüncü biçim otundan elde edilmiştir. En az HP ise son (\%13.41) ve ilk biçimdeki (\%13.98) otlardan sağlanmıştır (Çizelge 2).

Ham kül (HK) orant: Varyans analizi sonucuna göre, otun HK oranı bırakılan anız yükseklikleri ve biçim sayısına göre önemli bulunmamıştır. Anız yüksekliklerine göre otun HK içeriği \%9.13-11.65, biçim sayılarına göre ise \%7.49-10.52 arasında değişim göstermiştir (Çizelge 2).

NDF ve ADF oranları: Değişik anız yükseklikleri kalacak şekilde biçilen arpa otunun NDF oranı sadece biçim sayısına göre istatistiki olarak önemlilik arz etmiştir. Anız yüksekliklerine göre NDF oranları \%56.99-60.06 arasında değişmiştir. Biçim sırasına göre en az NDF içeren otlar (\%52.95) ilk biçimde elde edilmiştir. Diğer biçimlerin otun önemli seviyede daha yüksek NDF oranına (\%61.43-64.02) sahip olmuştur. Benzer durum ADF oranında da belirlenmiştir (Çizelge 2).Sindirilebilir organik (SOM) ve kuru madde (SKM) oranları: Farklı anız yüksekliklerine göre otun SOM ve SKM oranları biçim sayılarına göre önemli olurken, anız yükseklikleri ve $\mathrm{AY}{ }^{*} \mathrm{BS}$ etkileşiminde önemsiz olmuştur. En yüksek SOM (\%54.21) ve SKM oranına (\%53.70) sahip arpa otu ilk biçimden sağlanmıştır. Daha sonraki biçimlerde otun sindirilebilirliği düzenli olarak azalmıştır. Anız yüksekliklerine göre SOM oranı \%46.18-48.74, SKM oran1 da \%46.12-48.09 arasında tespit edilmiştir (Çizelge 2).

Arpa otunun besleme değerlerini gösteren besin maddesi içerikleri bırakılan anız yüksekliklerine göre önemli değişim göstermemiştir. Bitkilerde genç dokular daha yüksek protoplazma ve daha düşük çeper maddelerine sahiptir (Lyons ve ark., 1999; Papachristou ve ark., 2005). Buna bağlı olarak da sindirilme oranları değişmektedir. Otun protein oranı yükselip NDF oranı düştükçe sindirilme oranı da artmaktadır (Jung ve Allen, 1995). Bitkilerde en genç dokular üst kısımlarda bulunmaktadır. $\mathrm{Bu}$ yüzden normal şartlarda yüksekten biçilen bitkilerde genç doku miktarı en fazla olduğu için, otun HP, SOM ve SKM oranlarının yüksek, hücre çeperi bileşenlerinin ise düşük çıkması beklenirdi. Ancak biçimler bitkilerin vejetatif gelişme dönemlerinin ortalarında (20-25 cm boya ulaştığında) yapıldığı için, besin maddesi içeriklerinde belirgin bir değişim ortaya çıkmamış olabilir.Bitkilerde gelişmenin ilerlemesi ile birlikte protein oranında azalmalar ve hücre çeperi maddelerinde artışlar olmaktadır (Haddi ve ark., 2003; Kaya, 2008; Aydoğan ve ark., 2014). Bu sebeple arpa, yulaf ve tritikale ile yapılan çalışmada olgunlaşmanın ilerlemesine bağlı olarak otun ham protein içeriğinde azalma kaydedilmiştir (Khorasani ve ark., 1997). Benzer şekilde arpa, buğday, çavdar, yulaf ve tritikale ile yapılan çalışmada büyümenin ilerlemesine bağlı olarak otun ham protein içeriklerinde $\% 42$ oranında düşüşler tespit edilmiştir (Coşkun ve ark., 2014). Yine domuz ayrığı ile yapılan çalışmada da olgunlaşma ile otun NDF, ADF ve ADL oranlarında artış, ham protein oranında ise azalma olduğu belirtilmiştir (Can ve Ayan, 2017). Ayrica zamanın ilerlemesi ile havaların 1sınması buğdaygilleri vejetatif gelişmeye son vermeye itmektedir. $\mathrm{Bu}$ durumda bitkiler erken biçilse bile, yaprak/sap oranı azalmakta ve bitkilerde yeşil dokular azalmaya başlamaktadır. $\mathrm{Bu}$ değişim (kartlaşma) buğdaygillerde daha belirgin olarak ortaya çıkmaktadır (Miller, 1984). Bu yüzden biçim sayısı arttıkça HP ve sindirilebilirlik azalmış, çeper maddeleri artmıştır.

\section{SONUÇ}

Meraların yükünü hafifletmek ve erken otlatılmasını önlemek amacıyla tahıl meraları önemli bir seçenektir. $\mathrm{Bu}$ nedenle bu çalışmada arpa ile kurulacak tahıl merasında uygun anız yükseklikleri ele alınmıştır. Anız yükseklikleri $5,7.5$ ve $12.5 \mathrm{~cm}$ olan uygulamalar üç kez, 10 ve $15 \mathrm{~cm}$ olan uygulamalar ise dört kez biçilmiştir. Aralarındaki fark önemli olmamakla birlikte, en yüksek yeşil ve kuru ot verimleri $10 \mathrm{~cm}$ anız kalacak şekilde yapılan biçimlerden elde edilmiştir. Ot verimleri biçim sayısına bağlı olarak azalmıştır. Otun ham protein, NDF ve ADF oranları biçim yüksekliğinin artışına bağlı olarak önemsiz düzeyde olsa da artarken, ham kül, SOM ve SKM oranlarında azalma olmuştur. Bitkiler genel olarak 161 günde otlatma olgunluğuna gelmiştir. Bırakılan anız yüksekliklerine göre biçimler arasındaki süre 11-42 gün arasında değişmiştir. Buna göre, arpa ile oluşturulan meralarda bitkiler $20-25 \mathrm{~cm}$ boylandıklarında otlatmaya başlanması ve $10 \mathrm{~cm}$ anız kalınca da son verilmesinin uygun bir yönetim tarzı olacağı sonucuna ulaşılmıştır.

\section{KAYNAKÇA}

AOAC 1990. Official Methods of Analysis (15th Ed.). Association of Official Analytical Chemists, Arlington, VA.

Aydoğan S, Işık Ş, Şahin M, Göçmen Akçacık A, Hamzaoğlu S, Doğan Ş, Küçükcongar M, Ateş S 2014. Farklı biçim zamanlarının yem bitkilerinin besin maddesi kompozisyonuna Etkisi. Selçuk Tarım Bilimleri Dergisi, 1(2): 45-49.

Baytekin H, Yurtman IY, Savaş T 2005. Süt Keçiciliğinde Kaba Yem Üretim Organizasyonu. Süt Keçiciliği Ulusal Kongresi, 26-27 Mayıs 2005, İzmir.

Can M, Ayan İ 2017. Domuz ayrığı (Dactylis glomerata L.) popülasyonlarında gelişme dönemlerine göre verim ve bazı özelliklerin değişimi. KSÜ Doğa Bil. Dergisi, 20(2): 160-166.

Coşkun B, Keleş G, İnal F, Selçuk Alataş M, Özcan C, Ateş S 2014. Gebeleme ve hamur olum döneminde hasat edilen buğdaygil hasillarının protein fraksiyonları ve ham protein üretimleri. Kafkas Univ. Vet. Fak. Dergisi, 20(3): 457-460.

Gökkuş A, Hakyemez BH 2001. Buğdayın mera bitkisi olarak kullanımı ve önemi. Tarım ve Köy, Sayı: 139: 24-27.

Gökkuş A, Hakyemez BH, Yurtman IYY, Savaş T 2005. Farklı Mera Tiplerinde Otlatma Yoğunluklarının Meranın Ot Verimi ve Bitki Kompozisyonu ile Keçilerin Verim ve Davranışlarına Etkileri (Kesin 
Rapor). TÜBİTAK, TOVAG, Proje No: VHAG$1884,55 \mathrm{~s}$.

Haddi ML, Filacorda S, Meniai K, Rollin F, Susmel P 2003. In vitro fermentation kinetics of some halophyte shrubs sampled at three stages of maturity. Anim. Feed Sci. and Tech., 104: 215-225.

Hennessy G, Clements B 2009. Cereals for Grazing. NSW Department of Primary Industries, Primefact $720,4 \mathrm{p}$.

Joyce JP, Rattray PV, Parker J 1971. The Utilization of Pasture and barley by rabbits. I. Feed intakes and live-weight gains. New Zealand Journal of Agric. Res., 14(1): 173-179.

Jung HG, Allen MS 1995. Characteristics of plant cell walls affecting intake and digestibility of forages by ruminants. J., Anim. Sci., 73:2774-2790.

Kaya Ş 2008. Kaba yemlerin değerlendirilmesinde göreceli yem değeri ve göreceli kaba yem indeksi. Türk Bilimsel Derlemeler Derg., 1(1): 59-64.

Khorasani GR, Jedel PE, Helm JH, Kennelly JJ 1997. Influence of stage of maturity on yield components and chemical composition of cereal grain silages. Can. J. Anim. Sci., 77: 259-267.
Krenzer G 1994. Wheat for Pastures. Oklahoma State Univ. Coop. Ext. Serv., F-2586, 6 p.

Lyons RK, Machen RV, Forbes TDA 1999. Why Range Forage Quality Changes. Texas Agric. Ext. Serv., B-6036, p: 7.

Miller DA 1984. Forage Crops. McGraw Hill Book Co., New York, N.Y.

Ouédraogo-Koné S, Kaboré-Zoungrana CY, Ledin I 2006. Behaviour of goats, sheep and cattle on natural pasture in the sub-humid zone of West Africa. Livestock Science, 105: 224-252.

Papachristou TG, Platis PD, Nastis AS 2005. Foraging behaviour of cattle and goats in oak forest stands of varying coppicing age in Northern Greece. Small Ruminant Res., 59: 181-189.

Pinchak WE, Hunt LJ, Worral WD, Green LW, Caldwell SP, Worral NJ, Hutcheson DP 1989. Herbage Production and Nutritive Value of Small Grain Forages. Forage Research in Texas, 46-49.

Van Soest PJ, Robertson JB, Lewis BA 1991. Methods for dietary fiber, neutral detergent fiber, and nonstarch polysaccharides in relation to animal nutrition. J. Dairy Sci., 74, 3583-3597. 